\title{
Zika Virus Seropositivity in 1-4-Year-Old Children, Indonesia, 2014
}

\section{R. Tedjo Sasmono, Rama Dhenni, Benediktus Yohan, Paul Pronyk \\ Sri Rezeki Hadinegoro, Elizabeth Jane Soepardi, Chairin Nisa Ma'roef, Hindra I. Satari, Heather Menzies, William A. Hawley, \\ Ann M. Powers, Ronald Rosenberg, Khin Saw Aye Myint, Amin Soebandrio}

We assessed Zika virus seroprevalence among healthy 1-4-year-old children using a serum sample collection assembled in 2014 representing 30 urban sites across Indonesia. Of 662 samples, 9.1\% were Zika virus seropositive, suggesting widespread recent Zika virus transmission and immunity. Larger studies are needed to better determine endemicity in Indonesia.

$\mathrm{Z}$ ika virus, first isolated in 1947 (1), is a flavivirus phylogenetically related to dengue virus (DENV) that is, like DENV, also transmitted by Aedes mosquitoes. Because of the epidemic that swept through the Americas in 2016, Zika virus infection is known to cause microcephaly, as well as other congenital defects and Guillain-Barré syndrome (2).

Zika virus has long been known to be endemic in Southeast Asia $(3,4)$, but laboratory confirmation of infection can be challenging. Acute infections are often asymptomatic. In those who are symptomatic, viral RNA typically persists in blood $<7$ days and in urine $<10$ days after symptom onset, limiting the usefulness of nucleic acid testing (5). Zika virus antibody cross-reacting with DENV can confuse results of tests conducted in regions where the viruses co-circulate (6). Virus-specific neutralization assays can more accurately detect and measure Zika virus

Author affiliations: Eijkman Institute for Molecular Biology, Jakarta, Indonesia (R.T. Sasmono, R. Dhenni, B. Yohan, C.N. Ma'roef, K.S.A. Myint, A. Soebandrio); UNICEF Indonesia, Jakarta (P. Pronyk); University of Witwatersrand School of Public Health, Johannesburg, South Africa (P. Pronyk); Universitas Indonesia Medical School, Jakarta (S.R. Hadinegoro, H.I. Satari); Cipto Mangunkusumo Hospital, Jakarta (S.R. Hadinegoro, H.I. Satari); Ministry of Health of the Republic of Indonesia, Jakarta (E.J. Soepardi); Centers for Disease Control and Prevention, Atlanta, Georgia, USA (H. Menzies, W.A. Hawley); Centers for Disease Control and Prevention, Fort Collins, Colorado, USA (A.M. Powers, R. Rosenberg)

DOI: https://doi.org/10.3201/eid2409.180582 antibody, but because of their complex requirements, these tests have seldom been used in epidemiologic studies (7).

Acute Zika virus cases have been reported in Indonesia (8), Singapore (9), Malaysia (10), Vietnam (11), and Thailand (12). However, little is known about Zika virus prevalence in the region. Limited retrospective testing of archived specimens collected from clinically ill patients in Thailand (12) and Cambodia (13) suggest that incidence in these countries is low. However, given the limited number of samples tested and lack of confirmatory testing in these studies, information on prevalence and distribution is challenging to assess. Likewise, little is known about the prevalence and geographic distribution of Zika virus in Indonesia, the biggest country in Southeast Asia.

DENV and chikungunya virus, also transmitted by Aedes mosquitoes, are endemic throughout Indonesia, suggesting the ecologic conditions exist for Zika virus transmission as well. An estimated $80 \%$ of the population in Indonesia is infected with $\geq 1$ DENV by the age of 10 years (14). In our study, we assessed Zika virus seroprevalence among healthy 1-4-year-old children to determine the prevalence and distribution of Zika virus in Indonesia.

\section{The Study}

We used serum samples collected during October-November 2014 for a previous population-based, cross-sectional cluster survey conducted to assess DENV seroprevalence; in the study, 3,312 samples were collected from 1-18-yearold children in 30 urban districts in 14 provinces of Indonesia (14). In our study, we assessed only the children 1-4 years (range 12-59 months) of age because these children were least likely to have cross-reactive DENV antibodies. Ethics clearance was obtained from the Health Research Ethics Committee of the Faculty of Medicine, Universitas Indonesia, and the US Centers for Disease Control and Prevention (CDC; Atlanta, Georgia, USA).

Plaque reduction neutralization tests (PRNTs) that could differentiate Zika virus neutralizing antibodies from those produced in response to DENV infection were adapted from protocols developed by the CDC (online Technical Appendix, https://wwwnc.cdc.gov/EID/article/24/9/180582-Techapp1.pdf). The challenge virus used in the PRNT was Zika virus JMB-185, acquired from a patient in 2014 (8). Convalescent serum from this same patient was used as a PRNT positive control. We subjected all specimens 
to 2 tiers of testing by $\mathrm{PRNT}_{90}$ (i.e., a PRNT in which serum samples suppressing $\geq 90 \%$ of challenge virus were considered positive for neutralizing antibody). In the first tier, we tested serum samples diluted 1:10. Samples that suppressed $\geq 90 \%$ of Zika virus PFUs were considered potentially positive for Zika virus antibodies because DENVspecific antibodies, if present, could have cross-reacted and neutralized Zika virus. We then subjected the specimens considered potentially positive to a second $\mathrm{PRNT}_{90}$, in which we tested serum samples against Zika virus and all 4 DENV serotypes (online Technical Appendix). Specimens that tested positive for Zika virus neutralizing antibody and negative for DENV neutralizing antibody by $\mathrm{PRNT}_{90}$ were classified as Zika virus seropositive, as were specimens that had Zika virus PRNT $_{90}$ titers $\geq 4$-fold higher than all DENV PRNT $_{90}$ titers. We categorized specimens as flavivirus seropositive when Zika virus neutralizing antibodies were present but at titers $<4$-fold higher than any DENV neutralizing antibody titer (online Technical Appendix Table). We also tested a subset of samples for Japanese encephalitis virus antibody by $\mathrm{PRNT}_{90}$; none of the samples tested had a titer $>20$, and none of the sample classifications were changed after testing.

In the initial $\mathrm{PRNT}_{90}$ screening, we detected possible Zika virus antibody in 73 (11.0\%) of the 662 serum samples (Table). Of these, 72 had a sufficient volume to undergo second-tier testing; 60 (83.3\%) of 72 samples were Zika virus seropositive, and $12(16.7 \%)$ were flavivirus seropositive. Serum samples from 11 of 14 provinces were Zika virus seropositive, and the collections from the provinces ranged from $\approx 4.5 \%$ seropositive (North Sumatra, Banten, East Kalimantan) to $>18 \%$ seropositive (Central Java, Jambi; Figure). Overall, Zika virus seroprevalence in the 1-4-year-old cohort was 9.1\% (95\% CI 3.95\%-11.01\%).
Our assessment, involving use of the $\mathrm{PRNT}_{90}$, which is highly specific for Zika virus antibodies, indicates widespread, recent Zika virus infection in much of western and central Indonesia. Our criterion for confirmed Zika virus antibodies (i.e., PRNT $_{90}$ titer for Zika virus $\geq 4$-fold higher than that for any DENV in the same specimen) is the international standard. In just 2\% (12/662) of specimens, we could not determine whether the antibodies were Zika virus or DENV specific. When using the more conservative criterion of only classifying a sample as positive for Zika virus antibodies if no DENV-specific neutralizing antibodies are detected, the number of Zika virus antibody-positive samples decreases by only 6 , leaving 54 samples still classified as Zika virus seropositive. Further evidence for the validity of the $\mathrm{PRNT}_{90}$ was that DENV neutralizing antibody-positive samples were negative for the presence of Zika virus neutralizing antibodies across a range of titers (R.T. Sasmono, unpub. data).

Although our data provide some evidence regarding geographic distribution, no information is presented regarding a specific threshold titer associated with clinical illness or a correlation between geography and titer. Further studies involving larger sample sets would be necessary to address these topics. The single age group, relatively small number of specimens, and limited number of sites, particularly from eastern parts of the country, do not give a comprehensive picture of endemicity throughout Indonesia. The small numbers of specimens available from most localities did not enable accurate estimation of the proportional differences between localities. We could perform $\mathrm{PRNT}_{90}$ with samples from the remaining cohort (the 5-18-year-olds), but we expect higher percentages of nonspecific flavivirus seropositivity in the samples from this older age group.

\begin{tabular}{|c|c|c|c|}
\hline \multirow[b]{2}{*}{ Province } & \multicolumn{3}{|c|}{ Serologic status, \% (no. positive samples/total samples) } \\
\hline & Suspected Zika virus seropositive† & Confirmed Zika virus seropositiveł & Flavivirus seropositive§ \\
\hline Aceh & $0(0 / 22)$ & $0(0 / 22)$ & $0(0 / 22)$ \\
\hline North Sumatra & $9.1(2 / 22)$ & $4.5(1 / 22)$ & $4.5(1 / 22)$ \\
\hline West Sumatra & $18.2(4 / 22)$ & $13.6(3 / 22)$ & $4.5(1 / 22)$ \\
\hline Jambi & $18.2(4 / 22)$ & $18.2(4 / 22)$ & $0(0 / 22)$ \\
\hline Lampung & $8.7(2 / 23)$ & $8.7(2 / 23)$ & $0(0 / 23)$ \\
\hline Banten & $4.4(2 / 45)$ & $4.4(2 / 45)$ & $0(0 / 45)$ \\
\hline DKI Jakarta & $10.6(7 / 66)$ & $10.6(7 / 66)$ & $0(0 / 66)$ \\
\hline West Java & $11.1(17 / 153)$ & $8.5(13 / 153)$ & $2.0(3 / 153)$ \\
\hline Central Java & $20.5(18 / 88)$ & $18.2(16 / 88)$ & $2.3(2 / 88)$ \\
\hline East Java & $11.7(13 / 111)$ & $9.0(10 / 111)$ & $2.7(3 / 111)$ \\
\hline Bali & $0(0 / 22)$ & $0(0 / 22)$ & $0(0 / 22)$ \\
\hline East Kalimantan & $4.5(1 / 22)$ & $4.5(1 / 22)$ & $0(0 / 22)$ \\
\hline South Sulawesi & $0(0 / 22)$ & $0(0 / 22)$ & $0(0 / 22)$ \\
\hline Southeast Sulawesi & $13.6(3 / 22)$ & $4.5(1 / 22)$ & $9.1(2 / 22)$ \\
\hline All provinces & 11.0 (73/662), 95\% Cl 5.34-13.32 & 9.1 (60/662), 95\% Cl 3.95-11.01 & $1.8(12 / 662), 95 \% \mathrm{Cl} 0.23-3.35$ \\
\hline
\end{tabular}




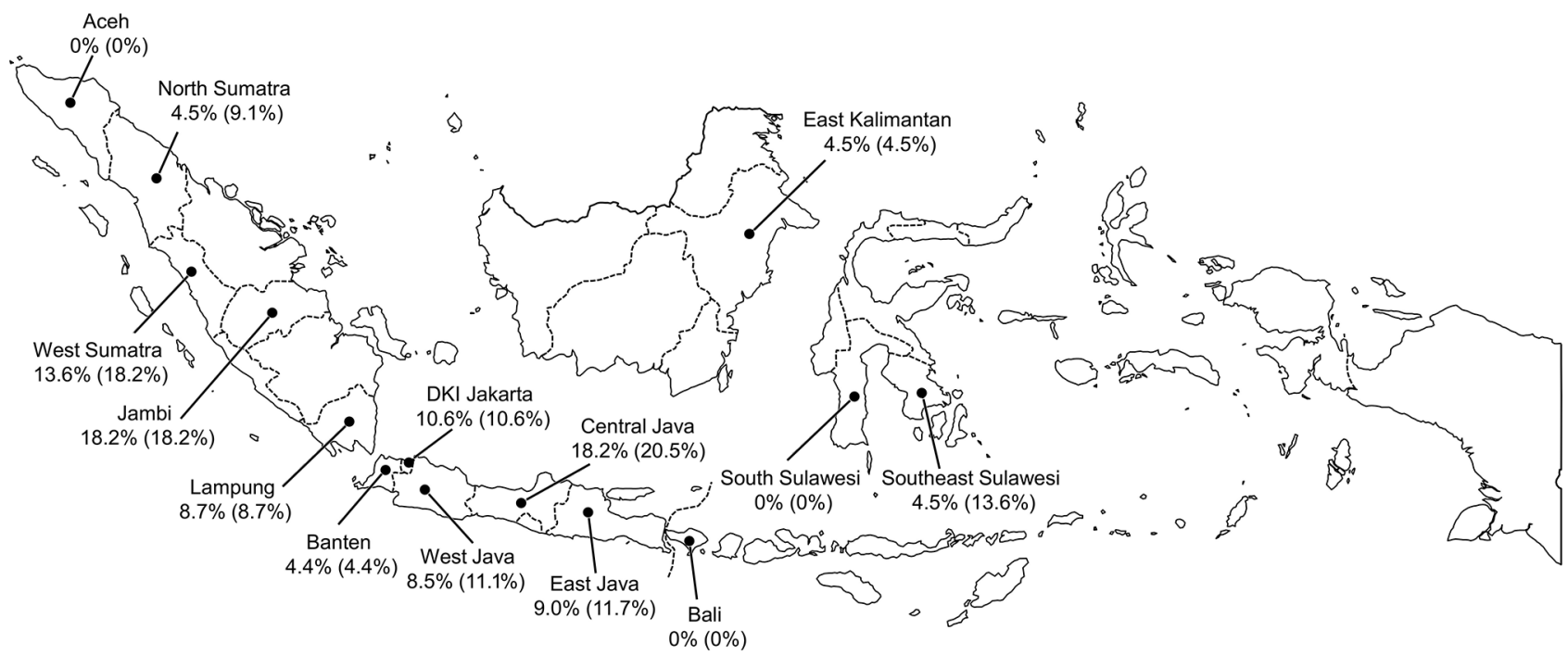

Figure. Geographic distribution of Zika virus-seropositive 1-4-year-old children, Indonesia, October-November, 2014. The values listed for each province indicate the percentage of serum samples confirmed Zika virus seropositive (percentage serum samples suspected to be Zika virus seropositive). Samples suspected to be Zika virus positive were those that were positive on initial Zika virus PRNT (plaque reduction neutralization test with neutralization defined as $\geq 90 \%$ reduction in challenge virus PFUs) screening when using a 1:10 serum sample dilution. Serum samples confirmed as Zika virus seropositive were those that neutralized Zika virus only or had a $\mathrm{PRNT}_{90}$ titer for Zika virus that was $\geq 4$-fold higher than the PRNT 90 titer for any DENV.

\section{Conclusions}

Much has been published on epidemic Zika virus, but little is known about the effect of Zika virus in endemic areas. Determining the prevalence of Zika virus in Indonesia can provide clues to its potential long-term public health significance in endemic settings. Mild or asymptomatic infection is common, and confusion with dengue during diagnosis probably accounts for how long Zika virus was unrecognized in Indonesia and other areas of Southeast Asia. Besides the need to better evaluate Zika virus incidence and distribution, a high priority for future investigations will be determining the extent of Zika virus-related birth defects. If, like other flaviviruses, a primary Zika virus infection results in lifelong immunity, infections during childhood could reduce a person's risk for infection later in life and thus the incidence of Zika virus-related birth defects. This knowledge provides clues for understanding future patterns of Zika virus transmission in the Americas.

\section{Acknowledgments}

We thank Alain Bouckenooghe and the DNG26 team for specimen collection. Help from Jeremy P. Ledermann and Araniy Fadhilah regarding PRNTs was greatly appreciated.

This work was supported by the Ministry of Research, Technology, and Higher Education of the Republic of Indonesia and CDC, Atlanta, Georgia, USA. Funding for this work was also provided by the Office of Infectious Diseases, Bureau for Global Health, US Agency for International Development, under the terms of an interagency agreement with CDC.

\section{About the Author}

Dr. Sasmono is a senior research fellow at the Eijkman Institute for Molecular Biology, Jakarta, Indonesia. His primary research interests are dengue and other arboviral diseases.

\section{References}

1. Dick GWA, Kitchen SF, Haddow AJ. Zika virus. I. Isolations and serological specificity. Trans R Soc Trop Med Hyg. 1952;46:50920. http://dx.doi.org/10.1016/0035-9203(52)90042-4

2. World Health Organization. WHO statement on the first meeting of the International Health Regulations (2005) (IHR 2005) Emergency Committee on Zika virus and observed increase in neurological disorders and neonatal malformations. 2016 Feb 1 [cited 2018 Apr 4]. http://www.who.int/mediacentre/news/statements/2016/ 1st-emergency-committee-zika/en/

3. Musso D, Gubler DJ. Zika virus. Clin Microbiol Rev. 2016;29:487524. http://dx.doi.org/10.1128/CMR.00072-15

4. Duong V, Dussart P, Buchy P. Zika virus in Asia. Int J Infect Dis. 2017;54:121-8. http://dx.doi.org/10.1016/j.ijid.2016.11.420

5. Paz-Bailey G, Rosenberg ES, Doyle K, Munoz-Jordan J, Santiago GA, Klein L, et al. Persistence of Zika virus in body fluids-preliminary report. N Engl J Med. 2017;NEJMoa1613108. http://dx.doi.org/10.1056/NEJMoa1613108

6. Lanciotti RS, Kosoy OL, Laven JJ, Velez JO, Lambert AJ, Johnson AJ, et al. Genetic and serologic properties of Zika virus associated with an epidemic, Yap State, Micronesia, 2007. Emerg Infect Dis. 2008;14:1232-9. http://dx.doi.org/10.3201/ eid1408.080287

7. Posen HJ, Keystone JS, Gubbay JB, Morris SK. Epidemiology of Zika virus, 1947-2007. BMJ Glob Health. 2016;1:e00087. http://dx.doi.org/10.1136/bmjgh-2016-000087

8. Perkasa A, Yudhaputri F, Haryanto S, Hayati RF, Ma'roef CN, Antonjaya $\mathrm{U}$, et al. Isolation of Zika virus from febrile patient, Indonesia. Emerg Infect Dis. 2016;22:924-5. http://dx.doi.org/ 10.3201/eid2205.151915 
9. Ho ZJM, Hapuarachchi HC, Barkham T, Chow A, Ng LC, Lee JMV, et al.; Singapore Zika Study Group. Outbreak of Zika virus infection in Singapore: an epidemiological, entomological, virological, and clinical analysis. Lancet Infect Dis. 2017;17:813-21. http://dx.doi.org/10.1016/ S1473-3099(17)30249-9

10. Salehuddin AR, Haslan H, Mamikutty N, Zaidun NH, Azmi MF, Senin MM, et al. Zika virus infection and its emerging trends in Southeast Asia. Asian Pac J Trop Med. 2017;10:211-9. http://dx.doi.org/10.1016/j.apjtm.2017.03.002

11. Chu DT, Ngoc VTN, Tao Y. Zika virus infection in Vietnam: current epidemic, strain origin, spreading risk, and perspective. Eur J Clin Microbiol Infect Dis. 2017;36:2041-2. http://dx.doi.org/ 10.1007/s10096-017-3030-8

12. Buathong R, Hermann L, Thaisomboonsuk B, Rutvisuttinunt W, Klungthong C, Chinnawirotpisan P, et al. Detection of Zika virus infection in Thailand, 2012-2014. Am J Trop Med Hyg. 2015;93:380-3. http://dx.doi.org/10.4269/ajtmh.15-0022

13. Duong V, Ong S, Leang R, Huy R, Ly S, Mounier U, et al. Low circulation of Zika virus, Cambodia, 2007-2016. Emerg Infect Dis. 2017;23:296-9. http://dx.doi.org/10.3201/eid2302.161432

14. Prayitno A, Taurel A-F, Nealon J, Satari HI, Karyanti MR, Sekartini R, et al. Dengue seroprevalence and force of primary infection in a representative population of urban dwelling Indonesian children. [erratum in PLoS Negl Trop Dis. 2018;12:e0006467]. PLoS Neg1 Trop Dis. 2017;11:e0005621. http://dx.doi.org/10.1371/journal.pntd.0005621

Address for correspondence: R. Tedjo Sasmono, Eijkman Institute for Molecular Biology, J1 Diponegoro 69, Jakarta 10430, Indonesia; email: sasmono@eijkman.go.id

\section{O \\ EID Podcast: Probable Unusual Transmission of Zika Virus}

Zika virus (ZIKV), a mosquito-transmitted flavivirus, has been isolated from sentinel monkeys, mosquitoes, and sick persons in Africa and Southeast Asia. Serologic surveys indicate that ZIKV infections can be relatively common among persons in southeastern Senegal and other areas of Africa, but that ZIKV-associated disease may be underreported or misdiagnosed. In 2007, a large outbreak of ZIKV infection occurred on Yap Island in the southwestern Pacific that infected $\approx 70 \%$ of the island's inhabitants, which highlighted this virus as an emerging pathogen. The purpose of this study was to investigate and report 3 unusual cases of arboviral disease that occurred in Colorado in 2008.

Clinical and serologic evidence indicates that two American scientists contracted Zika virus infections while working in Senegal in 2008. One of the scientists transmitted this arbovirus to his wife after his return home. Direct contact is implicated as the transmission route, most likely as a sexually transmitted infection.
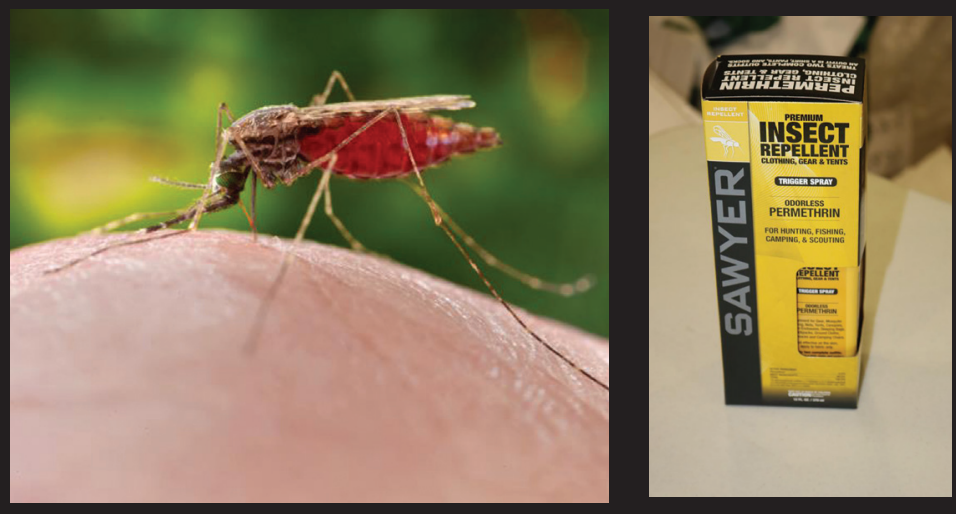

EMEREING INFECTIOUS DISEASES

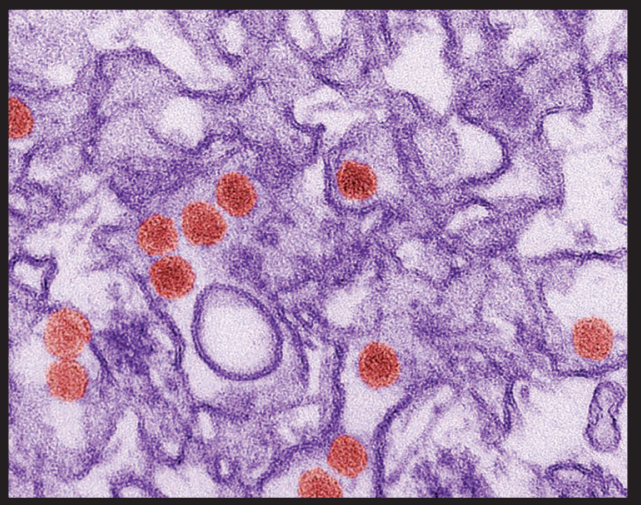

Visit our website to listen: https://www2c.cdc.gov/ podcasts $/$ player.asp?f $=7106489$ 